\title{
Article \\ Hydrogen Sulfide Interacts with 5-Aminolevulinic Acid to Enhance the Antioxidant Capacity of Pepper (Capsicum annuum L.) Seedlings under Chilling Stress
}

\author{
Huiping Wang, Zeci Liu, Jing Li, Shilei Luo, Jing Zhang and Jianming Xie *(D)
}

check for updates

Citation: Wang, H.; Liu, Z.; Li, J.; Luo, S.; Zhang, J.; Xie, J. Hydrogen Sulfide Interacts with 5-Aminolevulinic Acid to Enhance the Antioxidant Capacity of Pepper (Capsicum annuum L.) Seedlings under Chilling Stress. Agronomy 2022, 12, 572. https:// doi.org/10.3390/agronomy12030572

Academic Editor: Julián Cuevas González

Received: 18 January 2022 Accepted: 24 February 2022 Published: 25 February 2022

Publisher's Note: MDPI stays neutral with regard to jurisdictional claims in published maps and institutional affiliations.

Copyright: (C) 2022 by the authors. Licensee MDPI, Basel, Switzerland. This article is an open access article distributed under the terms and conditions of the Creative Commons Attribution (CC BY) license (https:// creativecommons.org/licenses/by/ $4.0 /)$.
College of Horticulture, Gansu Agriculture University, Lanzhou 730070, China; wanghp@st.gsau.edu.cn (H.W.); liuzc@gsau.edu.cn (Z.L.); lj@gsau.edu.cn (J.L.); luosl@gsau.edu.cn (S.L.); zj@gsau.edu.cn (J.Z.)

* Correspondence: xiejianming@gsau.edu.cn

\begin{abstract}
Aminolevulinic acid (ALA) is the precursor of tetrapyrrole synthesis, and hydrogen sulfide $\left(\mathrm{H}_{2} \mathrm{~S}\right)$ is a gas signal molecule. Studies have shown that exogenous ALA and $\mathrm{H}_{2} \mathrm{~S}$ can alleviate abiotic stress. This study evaluated the roles of ALA and $\mathrm{H}_{2} \mathrm{~S}$ and their interactions in regulating antioxidant activity in pepper seedlings under chilling stress. Chilling stress significantly inhibited the growth of pepper seedlings and increased the amounts of hydrogen peroxide $\left(\mathrm{H}_{2} \mathrm{O}_{2}\right)$, superoxide anion $\left(\mathrm{O}_{2}{ }^{\bullet-}\right)$, and malondialdehyde (MDA). ALA and / or $\mathrm{H}_{2} \mathrm{~S}$ increased the activities of superoxide dismutase (SOD), peroxidase (POD), and catalase (CAT). Moreover, ALA and / or $\mathrm{H}_{2} \mathrm{~S}$ enhanced the ascorbate (AsA)-glutathione (GSH) cycle by increasing the contents of AsA and GSH, the ratio of AsA to dehydroascorbic acid and GSH to glutathione disulfide increased, and the activities of ascorbate peroxidase (APX), glutathione reductase (GR), dehydroascorbate reductase (DHAR) and monodehydroascorbate reductase (MDHAR) also increased. At the transcriptional level, ALA and/or $\mathrm{H}_{2} \mathrm{~S}$ upregulated the expressions of $\mathrm{CaSOD}, \mathrm{CaPOD}, \mathrm{CaCAT}, \mathrm{CaAPX}, \mathrm{CaGR}, \mathrm{CaDHAR}$, and CaMDHAR in seedlings under chilling stress. ALA and / or $\mathrm{H}_{2} \mathrm{~S}$ also reduced the contents of $\mathrm{H}_{2} \mathrm{O}_{2}, \mathrm{O}_{2}{ }^{\bullet-}$ and MDA, eventually mitigating the inhibitory effects of chilling stress on pepper seedling growth. The combination of ALA and $\mathrm{H}_{2} \mathrm{~S}$ had a better effect than ALA or $\mathrm{H}_{2} \mathrm{~S}$ alone. Moreover, ALA and $\mathrm{H}_{2} \mathrm{~S}$ interact to regulate the oxidative stress response of pepper seedlings under chilling stress.
\end{abstract}

Keywords: antioxidase activities; ascorbate-glutathione cycle; low temperature; reactive oxygen species; transcriptional regulation

\section{Introduction}

Pepper (Capsicum annuum L.) is an important vegetable and seasoning crop, which is typically thermophilous plant [1,2]. The normal growth temperature of pepper is $20-30{ }^{\circ} \mathrm{C}$, and the growth and development will be hindered if the temperature is below $15^{\circ} \mathrm{C}$ [2]. In winter and spring, chilling is the main abiotic stress that limits the growth, development and yield of pepper [1]. Chilling stress seriously affects plant growth, development, and metabolic pathways, leading to poor germination, leaf yellowing, reduced leaf expansion, wilt, and delayed seedling development [3]. Chilling stress can also change the structure and function of cell membranes [4]. Meanwhile, plants produce a large amount of reactive oxygen species (ROS), including singlet oxygen $\left({ }^{1} \mathrm{O}_{2}\right)$, hydrogen peroxide $\left(\mathrm{H}_{2} \mathrm{O}_{2}\right)$, hydroxyl radical $\left(\mathrm{HO}^{\bullet}\right)$, and superoxide anion $\left(\mathrm{O}_{2}{ }^{\bullet-}\right)$ under chilling stress, which cause cell oxidative damage when produced in excess [5-7]. ROS have a bidirectional effect in vivo. On the one hand, ROS led to irreversible DNA damage and cell death; on the other, ROS regulate plant growth and stress as signaling molecules [8,9]. ROS also regulate stomatal behavior, pathogen defense, and programmed cell death $[8,10,11]$. Plants have a complex and complete antioxidant system to remove ROS and protect cells from oxidative damage $[6,10]$. The antioxidant systems in living organisms mainly depend on antioxidant molecules, antioxidant enzymes, and some osmotic regulatory substances [11,12]. 
Antioxidant molecules include glutathione (GSH), ascorbate (AsA), and $\alpha$-tocopherol [11]. Among the antioxidant pathways, the AsA-GSH cycle is considered to be the most important, which is regulated by four key enzymes: glutathione reductase (GR), ascorbate peroxidase (APX), monodehydroascorbate reductase (MDHAR) and dehydroascorbate reductase (DHAR) [13]. Antioxidant enzymes include catalase (CAT), peroxidase (POD), superoxide dismutase (SOD), APX, and other antioxidant enzymes [11,13].

ALA, a precursor of the synthesis of tetrapyrrole (chlorophyll, heme and cyrheme), is a novel plant growth regulator and plays important roles in plants [14-16]. ALA enhances plant growth, yield, and abiotic stress tolerance by regulating antioxidant mechanisms, photosynthesis, and nutrient uptake [17]. Exogenous ALA can also ameliorate oxidative stress caused by low-temperature stress in tomato, cucumber, soybean, mung bean and maize $[5,15,18-20]$. Moreover, under chilling stress, the activities of antioxidant enzymes (APX, GPX, SOD, and POD) increased in rice [21]. Excepting the activities of antioxidant enzymes (SOD, CAT, APX, DHAR, and GR), the ratio of GSH to glutathione disulfide (GSSG) and AsA to dehydroascorbic acid (DHA) in tomato were also significantly increased under chilling [13].

As a vital gas signaling molecule, hydrogen sulfide $\left(\mathrm{H}_{2} \mathrm{~S}\right)$, plays a crucial role in promoting tolerance to environmental stress and mitigating the adverse effects of stress on plants [22,23]. $\mathrm{H}_{2} \mathrm{~S}$ is involved in the regulation of plant growth, development, and resistance to abiotic stress (cold, salinity, drought, and heavy metals) through interactions with ROS, hormones, and other molecular signals [7,24]. The effect of $\mathrm{H}_{2} \mathrm{~S}$ on abiotic stress is generally related to oxidative stress, and previous studies have shown that $\mathrm{H}_{2} \mathrm{~S}$ and ROS have both antagonistic and synergistic effects when regulating plant response to stress $[25,26]$. Chilling stress induces a short and rapid increase in endogenous $\mathrm{H}_{2} \mathrm{~S}$ in plants $[7,24,27]$. The application of sodium hydrosulfide ( $\mathrm{NaHS}$; an $\mathrm{H}_{2} \mathrm{~S}$ precursor) increased the activities of antioxidant enzymes in cucumber under chilling stress [27].

ALA has been reported to interact with nitric oxide (NO) to initiate cold tolerance in plants, and acts upstream of NO to respond to chilling tolerance by activating antioxidant defenses and plasma membrane (PM) $\mathrm{H}^{+}$-ATPase and maintaining $\mathrm{Na}$ and $\mathrm{K}$ homeostasis in the roots of Elymus nutans [28]. ALA also interacts with downstream signals $\left(\mathrm{H}_{2} \mathrm{O}_{2}, \mathrm{NO}\right.$, and jasmonic acid (JA)) to induce chilling tolerance in tomato [29]. $\mathrm{H}_{2} \mathrm{~S}$ was also shown to induce cold tolerance in cucumber through interactions with indole-3-acetic acid (IAA) and salicylic acid (SA) [27,30], and enhance the salt tolerance of alfalfa seed germination through the $\mathrm{NO}$ pathway [31]. $\mathrm{H}_{2} \mathrm{~S}$ may also be a downstream signaling molecule in heat tolerance induced by NO in maize seedlings [32]. The chromium tolerance of foxtail millet was found to be enhanced by the interaction of $\mathrm{H}_{2} \mathrm{~S}$ with calcium [33].

ALA or $\mathrm{H}_{2} \mathrm{~S}$ can regulate abiotic stress in plants by enhancing antioxidant activity. However, few studies focused on the relationship between $\mathrm{H}_{2} \mathrm{~S}$ and ALA in abiotic stress. In this study, we evaluated the roles of ALA and/or $\mathrm{H}_{2} \mathrm{~S}$ and their interactions in regulating oxidative stress in pepper seedlings by measuring the ROS content and malondialdehyde (MDA), antioxidant enzyme activity and transcription level of genes encoding their synthesis, and the AsA-GSH cycle under chilling stress.

\section{Materials and Methods}

\subsection{Plant Materials and Growth Conditions}

Pepper seeds (Hangjiao 2, Shenzhou lvpeng, Tianshui, China) were soaked in distilled water at $55{ }^{\circ} \mathrm{C}$ for $15 \mathrm{~min}$ and then soaked at room temperature for $6 \mathrm{~h}$. After this, the seeds were spread evenly on a wet towel and incubated in the dark for $3 \sim 5$ days at $28{ }^{\circ} \mathrm{C}$. After germinating, seeds were planted in the substrate (vermiculite: peat: cow dung $=1: 1: 1$ ) for growth. The pepper seedlings were grown in a light incubator under the following conditions: relative humidity $=50 \sim 75 \%$; temperature $=28{ }^{\circ} \mathrm{C} / 18{ }^{\circ} \mathrm{C}(12 \mathrm{~h}$ light $/ 12 \mathrm{~h}$ dark $)$; and light intensity $=300 \mu \mathrm{mol} \cdot \mathrm{m}^{-2} \cdot \mathrm{s}^{-1}$. 


\subsection{Treatments and Experimental Design}

Pepper seedlings were treated with chilling stress when they had grown six true leaves. Exogenous substances were sprayed before chilling stress: $1 \mathrm{mmol} / \mathrm{L} \mathrm{NaHS} \mathrm{(a} \mathrm{producer} \mathrm{of}$ $\mathrm{H}_{2} \mathrm{~S}$ ) and $150 \mu \mathrm{mmol} / \mathrm{L}$ hypotaurine (HT; an $\mathrm{H}_{2} \mathrm{~S}$ scavenger) were sprayed on the leaves $24 \mathrm{~h}$ before chilling stress, and $25 \mathrm{mg} / \mathrm{L}$ ALA solution was sprayed on the leaves $12 \mathrm{~h}$ after the spraying of HT and NaHS, following our previous research [34]. Each treatment contained 50 seedlings and each pot was sprayed with $10 \mathrm{~mL}$ of exogenous substances. The experimental treatments were as follows: regular training $\left(\mathrm{RT} ; 28^{\circ} \mathrm{C} / 18^{\circ} \mathrm{C}\right.$ day $/$ night temperature and $300 \mu \mathrm{mol} \cdot \mathrm{m}^{-2} \cdot \mathrm{s}^{-1}$ light intensity); chilling stress $\left(\mathrm{CK}, 10^{\circ} \mathrm{C} / 5^{\circ} \mathrm{C}\right.$ day $/$ night temperature and $100 \mu \mathrm{mol} \cdot \mathrm{m}^{-2} \cdot \mathrm{s}^{-1}$ light intensity); ALA ( $25 \mathrm{mg} / \mathrm{L}$ ALA and chilling stress); ALA + HT ( $25 \mathrm{mg} / \mathrm{L}$ ALA + $150 \mu \mathrm{mmol} / \mathrm{L} \mathrm{HT}$ and chilling stress); ALA + NaHS ( $25 \mathrm{mg} / \mathrm{L}$ ALA $+1 \mathrm{mmol} / \mathrm{L} \mathrm{NaHS}$ and chilling stress); and NaHS (1 mmol/L NaHS and chilling stress). All chilling stress was performed under the same conditions $\left(10{ }^{\circ} \mathrm{C} / 5^{\circ} \mathrm{C}\right.$ day /night temperature and $100 \mu \mathrm{mol} \cdot \mathrm{m}^{-2} \cdot \mathrm{s}^{-1}$ light intensity): the photoperiod of all treatments was $12 \mathrm{~h} / 12 \mathrm{~h}$ (light/dark), and the chilling stress was applied for a total of seven days.

\subsection{Biomass, Morphology, and Physiological Indexes}

After one week of chilling stress, 6 plants were selected from each treatment to measure the plant height, stem thickness, blade quantity, shoot fresh weight, and root fresh weight. The functional leaves of five well-grown seedlings functional leaves were mixed as one sample, and the physiological indexes (the contents of $\mathrm{H}_{2} \mathrm{O}_{2}, \mathrm{O}_{2}{ }^{\bullet-}$, malondialdehyde (MDA), GSH, GSSG, AsA, DHA, and antioxidant enzyme activities) were determined with three biological replicates of each using assay kits (Comin Biotechnology, Suzhou, China) after $24 \mathrm{~h}$ of chilling stress. Absorbance was determined using a UV-1780 spectrophotometer (Shimadzu, Kyoto, Japan).

\subsection{Histochemical Staining and the Contents of $\mathrm{H}_{2} \mathrm{O}_{2}, \mathrm{O}_{2}{ }^{\bullet-}$, and MDA}

The 3,3-diaminobenzidine (DAB) and nitroblue tetrazolium (NBT) staining were used to detect the accumulation of hydrogen peroxide and superoxide anion, respectively, after $24 \mathrm{~h}$ of low-temperature stress, and the detection method referred to in Reference [1].

The contents of $\mathrm{H}_{2} \mathrm{O}_{2}, \mathrm{O}_{2}{ }^{\bullet-}$, and MDA were measured using assay kits (Comin Biotechnology, Suzhou, China) following the manufacturer's instructions. $\mathrm{H}_{2} \mathrm{O}_{2}$ and titanium sulfate combine to form titanium peroxide, which exhibits absorption at $415 \mathrm{~nm}$. MDA and thiobarbituric acid are condensed into a red product with a maximum absorption at $532 \mathrm{~nm}$. The samples $(0.1 \mathrm{~g})$ were ground in ice bath with $1 \mathrm{~mL}$ of MDA extract, and then centrifuged at $8000 \times \mathrm{g}$ and $4{ }^{\circ} \mathrm{C}$ for $10 \mathrm{~min}$. The supernatant was used to determine MDA content following the manufacturer's instruction. The absorbance at $600 \mathrm{~nm}$ was measured, and the MDA content was calculated by the difference in the absorbance. $\mathrm{O}_{2}{ }^{\bullet-}$ reacts with hydroxylamine hydrochloride to form $\mathrm{NO}^{2-}$, which reacts with p-aminobenzene sulfonic acid and naphthalamine to form the azo compound of Mangrove Bay, which has a characteristic absorption peak at $530 \mathrm{~nm}$. The content of $\mathrm{O}_{2}{ }^{\bullet-}$ was calculated according to the difference between the measured value and the blank value.

\subsection{Antioxidant Enzyme Activities}

Fresh leaf samples $(0.1 \mathrm{~g})$ were ground in an ice bath with $1 \mathrm{~mL}$ of extract solution $(0.1 \mathrm{~mol} / \mathrm{L}$ sodium phosphate buffer, $\mathrm{pH}=7.8)$. The homogenate was then centrifuged at $8000 \times g$ and $4{ }^{\circ} \mathrm{C}$ for $10 \mathrm{~min}$. The supernatant was used to determine the activities of SOD, POD, and CAT using assay kits (Comin Biotechnology, Suzhou, China) following the manufacturer's instructions. SOD can remove $\mathrm{O}_{2}{ }^{\bullet-}$, which can react with WST-8 to form formazan, which shows absorption at $450 \mathrm{~nm}$. The activity of POD (EC 1.11.1.7) was determined according to manufacturer's instructions by determining absorbance values at $470 \mathrm{~nm}$ for 1 and $2 \mathrm{~min}$. at $470 \mathrm{~nm}$. The CAT (EC 1.11.1.6) activity was determined by initial and 2-min absorbance values at $240 \mathrm{~nm}$ according to the manufacturer's instructions. To determine the APX and GR activites after chilling stress for $24 \mathrm{~h}, 0.1 \mathrm{~g}$ leaf sample was 
ground with pre-cooled extract and then centrifuged at $13,000 \times \mathrm{g}$ and $4{ }^{\circ} \mathrm{C}$ for $20 \mathrm{~min}$. The supernatant was used to determine the activities of APX and GR following the manufacturer's instructions. Similarly, the activities of DHAR and MDHAR were determined using a common extract, which was centrifuged at $8000 \times g$ and $4{ }^{\circ} \mathrm{C}$ for $10 \mathrm{~min}$. Next, the activities of DHAR and MDHAR were determined using the supernatant according to the manufacturer's instructions.

\subsection{The Contents of GSH, GSSG, AsA, and DHA}

The contents of GSH, GSSG, AsA, and DHA were measured using assay kits (Comin Biotechnology, Suzhou, China). Fresh leaf samples $(0.1 \mathrm{~g})$ were homogenized with $1 \mathrm{~mL}$ of GSH extract solution in an ice bath and centrifuged at $8000 \times g$ for $10 \mathrm{~min}$. Supernatant $(100 \mu \mathrm{L})$ was used to determine the GSH and GSSG contents following the manufacturer's instructions. Similarly, AsA and DHA can also be extracted together. Fresh leaf samples $(0.1 \mathrm{~g})$ were homogenized with $1 \mathrm{~mL}$ AsA extract solution $(2 \mathrm{~mol} / \mathrm{L}$ acetic acid buffer, $\mathrm{pH}=4.5$ ) in an ice bath and centrifuged at $12,000 \times g$ for $20 \mathrm{~min}$. The supernatant was then used to determine the contents of AsA and DHA following the manufacturer's instructions. Finally, the GSH/GSSG and AsA/DHA ratios were calculated.

\subsection{RNA Extraction and qRT-PCR}

Total RNA from pepper leaves was isolated using an RNA extraction kit (Tiangen, Beijing, China). The quality and concentration of RNA were determined by ultramicro spectrophotometry (Pultton, Charlott, USA) and agarose gel electrophoresis. Genomic DNA was removed and RNA was reverse-transcribed using kit (TransGen Biotech, Beijing, China), and the quality and concentration of cDNA were determined by ultramicro spectrophotometry (Pultton, Charlott, USA). Then, cDNA was diluted to $150 \mathrm{ng} / \mu \mathrm{L}$ and used for qRT-PCR using kits (TransGen Biotech, Beijing, China), following the manufacturer's instructions. qRT-PCR was performed using a QuantStudio5 RT-PCR System (Thermo Fisher Scientific Inc., Waltham, USA). Each reaction included three biological and three technical replicates. Actin of pepper (Gene ID: 107875540) was used as the internal reference gene. All primers, including Actin and cDNA, were pretested for efficiency and reaction efficiency. The gene sequences were searched from the NCBI website (https: / / www.ncbi.nlm.nih.gov/gene, 1 February 2022). Primers were designed for qRT-PCR, and the sequences are shown in Table 1.

Table 1. Primers used for the qRT-PCR.

\begin{tabular}{|c|c|c|c|c|c|}
\hline Genes & Accessions & Forward Primer & TM & Reverse Primer & TM \\
\hline CaSOD & AF036936.2 & GCTTCATCACCAGAAACATCATCAGAC & 57.79 & ATGACCTCCGCCATTGAACTTGATAG & 58.83 \\
\hline CaPOD & FJ596178.1 & GCCATTACTGCTAGGGACTCTGTTG & 59.71 & GAAGTAGGAGGAGGAATGCTGCTATTG & 58.98 \\
\hline $\mathrm{CaCAT}$ & AB007190.1 & TTAACGCTCCCAAGTGTGCTCATC & 59.68 & GGGCAAATAATCCACСTCCTCATCG & 60.08 \\
\hline CaAPX & DQ002888.1 & GAGCAGTTTCCCACACTCTCCTATG & 59.47 & CATCAGGTCCTCCAGTAACTTCAACAG & 59.01 \\
\hline CaGR & AY547351.1 & GTTAATTCAACTGGATGGCACCAAGATG & 58.11 & ATTCCTGGACGATGAGCCCTACTAC & 60.19 \\
\hline $\mathrm{CaDHAR2}$ & JW079767.1 & CCGTCACTAGAATCCTTGCTCTTCAG & 59.17 & ТАСССАААТСССТСТСТСGTTАСТСС & 59.69 \\
\hline CaMDHAR & AY652702.1 & GAGCAAGACCACTCACGACTCTATTC & 59.07 & AACATCACCTACAGCGTACACATCAG & 58.60 \\
\hline CaActin & XM_016722297.1 & GTCCTTCCATCGTCCACAGG & 58.38 & GAAGGGCAAAGGTTCACAACA & 55.84 \\
\hline
\end{tabular}

\subsection{Statistical Analysis}

The data in this study are shown as the mean \pm standard error of three independent experiments. A statistical analysis was conducted using SPSS 22.0 (SPSS Institute Inc., Chicago, IL, USA). Duncan's test was used to assess significant differences among the means at a probability level of 5\%. All figures were created in Origin version 9 (OriginLab Institute Inc., Northampton, MA, USA).

\section{Results}

\subsection{Effects of $A L A$ and/or $\mathrm{H}_{2} \mathrm{~S}$ on the Growth of Pepper Seedlings under Chilling Stress}

Plant phenotypes were observed and photographed under chilling stress for $24 \mathrm{~h}$. After $24 \mathrm{~h}$ of chilling, low-temperature alone (CK) and ALA + HT treatments showed severe 
wilting, while ALA and NaHS alone showed lighter wilting than CK. ALA combined with

NaHS (ALA + NaHS) had almost no wilting (Figure 1A).

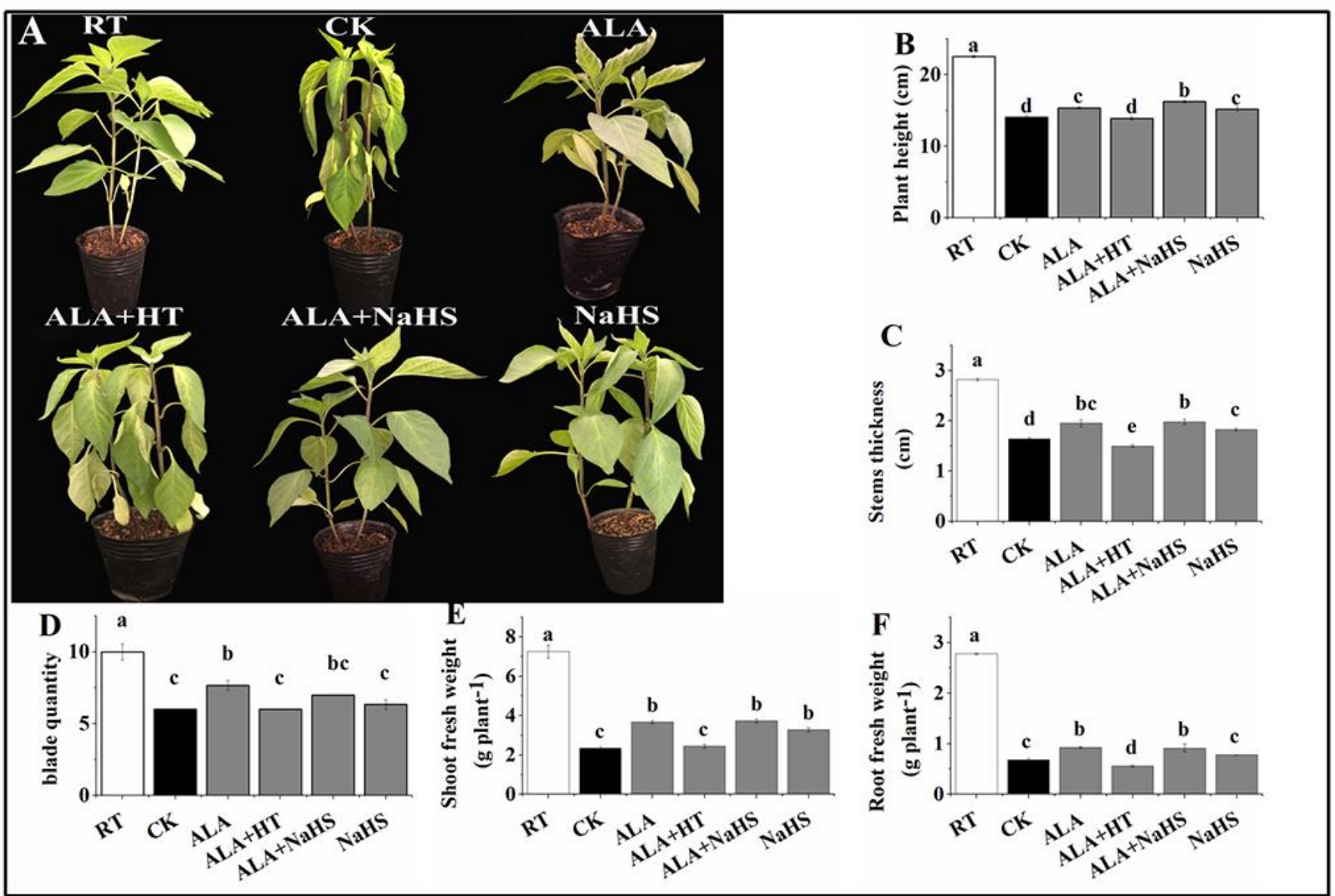

Figure 1. Effects of ALA and/or $\mathrm{H}_{2} \mathrm{~S}$ on the phenotype under chilling stress and the growth under chilling stress in pepper seedlings: (A) the phenotype under chilling stress for $24 \mathrm{~h}$, (B) plant height for 1 week, (C) stems thickness for 1 week, (D) blade quantity for 1 week, (E) shoot fresh weight for 1 week, and (F) root fresh weight for 1 week. NaHS: a producer of $\mathrm{H}_{2} \mathrm{~S}$; HT: an $\mathrm{H}_{2} \mathrm{~S}$ scavenger. $\mathrm{RT}$ : $28^{\circ} \mathrm{C} / 18^{\circ} \mathrm{C}$ day/night temperature and $300 \mu \mathrm{mol} \cdot \mathrm{m}^{-2} \cdot \mathrm{s}^{-1}$ light intensity; $\mathrm{CK}: 10^{\circ} \mathrm{C} / 5{ }^{\circ} \mathrm{C}$ day/night temperature and $100 \mu \mathrm{mol} \cdot \mathrm{m}^{-2} \cdot \mathrm{s}^{-1}$ light intensity); ALA: $25 \mathrm{mg} / \mathrm{L}$ $\mathrm{ALA}+10^{\circ} \mathrm{C} / 5^{\circ} \mathrm{C}$ day $/$ night temperature and $100 \mu \mathrm{mol} \cdot \mathrm{m}^{-2} \cdot \mathrm{s}^{-1}$ light intensity; ALA + HT: $25 \mathrm{mg} / \mathrm{L}$ $\mathrm{ALA}+150 \mu \mathrm{mmol} / \mathrm{L} \mathrm{HT}+10{ }^{\circ} \mathrm{C} / 5^{\circ} \mathrm{C}$ day $/$ night temperature and $100 \mu \mathrm{mol} \cdot \mathrm{m}^{-2} \cdot \mathrm{s}^{-1}$ light intensity); ALA + NaHS: $25 \mathrm{mg} / \mathrm{L}$ ALA $+1 \mathrm{mmol} / \mathrm{L} \mathrm{NaHS}+10{ }^{\circ} \mathrm{C} / 5{ }^{\circ} \mathrm{C}$ day/night temperature and $100 \mu \mathrm{mol} \cdot \mathrm{m}^{-2} \cdot \mathrm{s}^{-1}$ light intensity; NaHS: $1 \mathrm{mmol} / \mathrm{L} \mathrm{NaHS}+10^{\circ} \mathrm{C} / 5^{\circ} \mathrm{C}$ day/night temperature and $100 \mu \mathrm{mol} \cdot \mathrm{m}^{-2} \cdot \mathrm{s}^{-1}$ light intensity. The error bars are the standard errors for 6 independent tests. Different letters show significant differences $(p<0.05)$ based on Duncan's test.

The plant height, stem thickness, blade quantity, shoot fresh weight, and root fresh weight of seedlings were measured after one week of chilling stress. These indexes significantly decreased during chilling stress for one week (Figure 1B-F). Compared to chilling stress alone $(\mathrm{CK})$, the application of exogenous ALA increased the plant height, stem thickness, blade quantity, shoot fresh weight, and root fresh weight by $9.2 \%, 18.7 \%, 27.8 \%$, $56.8 \%$, and $36.9 \%$, respectively. Simultaneously, compared to CK, the application of exogenous NaHS increased the plant height, stem thickness, and shoot fresh weight by $8.06 \%, 11.2 \%$, and $40.4 \%$, respectively (Figure 1B,C,E). However, there was no significant difference in the blade quantity and root fresh weight between NaHS and CK treatments. In addition, compared to CK, ALA + NaHS treatment increased the plant height, stem thickness, shoot fresh weight, and root fresh weight by $15.4 \%, 20.5 \%, 59.9 \%$ and $35.0 \%$, 
respectively (Figure 1B,C,E,F). Meanwhile, the plant height, stem thickness, blade quantity, shoot fresh weight, and root fresh weight were significantly reduced in the group treated with ALA + HT compared to the ALA (Figure 1B-F). These results indicate that the application of exogenous ALA and/or $\mathrm{H}_{2} \mathrm{~S}$ significantly alleviated the growth-inhibiting effects of chilling stress in pepper seedlings. Meanwhile, HT inhibited the ability of ALA to alleviate the effects of chilling stress on pepper growth.

\subsection{Effects of $A L A$ and/or $\mathrm{H}_{2} \mathrm{~S}$ on $\mathrm{H}_{2} \mathrm{O}_{2}, \mathrm{O}_{2}{ }^{\bullet-}$, and $\mathrm{MDA}$ under Chilling Stress}

DAB and NBT staining reflected the accumulation of hydrogen peroxide and superoxide anion. CK and ALA + HT treatments showed deeper staining compared with other treatments, while ALA, NaHS and ALA + NaHS treatments showed a significantly lighter color than $\mathrm{CK}$ (Figure 2A,B). In addition, the $\mathrm{H}_{2} \mathrm{O}_{2}$ and $\mathrm{O}_{2}{ }^{\bullet-}$ contents and were measured after $24 \mathrm{~h}$ of chilling stress. Under chilling stress $(\mathrm{CK})$, the contents of $\mathrm{H}_{2} \mathrm{O}_{2}$ and $\mathrm{O}_{2}{ }^{\bullet-}$ increased by $138.6 \%$ and $34.2 \%$ compared to RT, respectively (Figure 2D,E). For the ALA, NaHS, and ALA + NaHS treatments, the $\mathrm{H}_{2} \mathrm{O}_{2}$ contents were decreased by $17.7 \%, 40.9 \%$, and $25.6 \%$, compared to CK, respectively, while the contents of $\mathrm{O}_{2}{ }^{\bullet-}$ were decreased by $16.7 \%, 14.5 \%$, and $19.5 \%$, respectively (Figure $2 \mathrm{D}, \mathrm{E}$ ). The MDA content indirectly reflects the degree of membrane lipid peroxidation. Compared to CK, the ALA, $\mathrm{NaHS}$, and ALA + NaHS treatments decreased the content of MDA by $24.0 \%, 28.0 \%$, and $25.6 \%$, respectively (Figure 2C). No significant differences were observed in the contents of $\mathrm{H}_{2} \mathrm{O}_{2}, \mathrm{O}_{2}^{\bullet-}$, and MDA between ALA + HT and CK under chilling stress (Figure 2C-E).

\subsection{Effects of $A L A$ and/or $\mathrm{H}_{2} \mathrm{~S}$ on the Activities of $\mathrm{SOD}, P O D$, and CAT under Chilling Stress}

To evaluate the antioxidant activity of pepper seedlings under chilling stress, we measured the activities of SOD, POD, and CAT along with the relative expression levels of the related genes. Compared to $\mathrm{CK}$, exogenous ALA increased the activities of SOD, POD, and CAT by $127.4 \%, 54.4 \%$, and $58.1 \%$ and the relative expression levels of CaSOD, CaPOD, and CaCAT by 10.1-, 30.7-, and 7-fold, respectively (Figure 3A-F). Compared to CK, exogenous $\mathrm{H}_{2} \mathrm{~S}$ significantly increased the activities of SOD, POD, and CAT by $124.4 \%$, $37.6 \%$, and $39.7 \%$, the relative expression levels of CaSOD, CaPOD, and CaCAT by 17.8-, 23-, and 4.9-fold, respectively (Figure 3A-F). ALA + NaHS significantly increased the activities of SOD, POD, and CAT by $115.3 \%, 48.9 \%$, and $50.77 \%$, and the relative expression levels of CaSOD, CaPOD, and CaCAT by 16.3-, 29.5-, and 6.6-fold compared to CK, respectively (Figure $3 \mathrm{~A}-\mathrm{F}$ ). Compared to the ALA group, the activities of SOD, POD, and CAT in the ALA + HT group were decreased by 34.9\%, 29.4\%, and 27.7\%, respectively (Figure 3A-C). Moreover, the relative expression levels of CaSOD, CaPOD, and CaCAT in the ALA + HT group were significantly lower than those in the ALA group (Figure 3D-F).

\subsection{Effects of ALA and/or $\mathrm{H}_{2} \mathrm{~S}$ on the Contents of GSH and GSSG under Chilling Stress}

The contents of GSH and GSSG after $24 \mathrm{~h}$ of chilling stress are shown in Figure 4. Chilling stress significantly reduced the content of GSH compared to RT, and ALA alleviated this effect of chilling stress (Figure 4A). However, NaHS treatment had no significant effect on GSH content compared to CK (Figure 4A). In contrast, chilling stress significantly increased the content of GSSG. Compared to CK, the ALA, ALA + HT, ALA + NaHS, and NaHS treatments decreased the GSSG content by $37.7 \%, 19.4 \%, 48.7 \%$, and 51.5\%, respectively (Figure 4B). Moreover, chilling stress significantly reduced the GSH/GSSG ratio compared to RT (Figure $4 \mathrm{C}$ ). The ALA, ALA+ NaHS, and NaHS treatments increased the GSH/GSSG ratio by 1.3-, 1.3-, and 1.1-fold compared to CK, respectively (Figure 4C). No significant difference in GSH/GSSG ratio was observed between the ALA + HT and CK groups (Figure 4C). These results suggest that ALA increased the GSH/GSSG ratio in pepper seedlings subjected to chilling stress for $24 \mathrm{~h}$ by increasing the GSH content and decreasing the GSSG content; meanwhile, $\mathrm{H}_{2} \mathrm{~S}$ increased the GSH/GSSG ratio primarily by decreasing the GSSG content. 

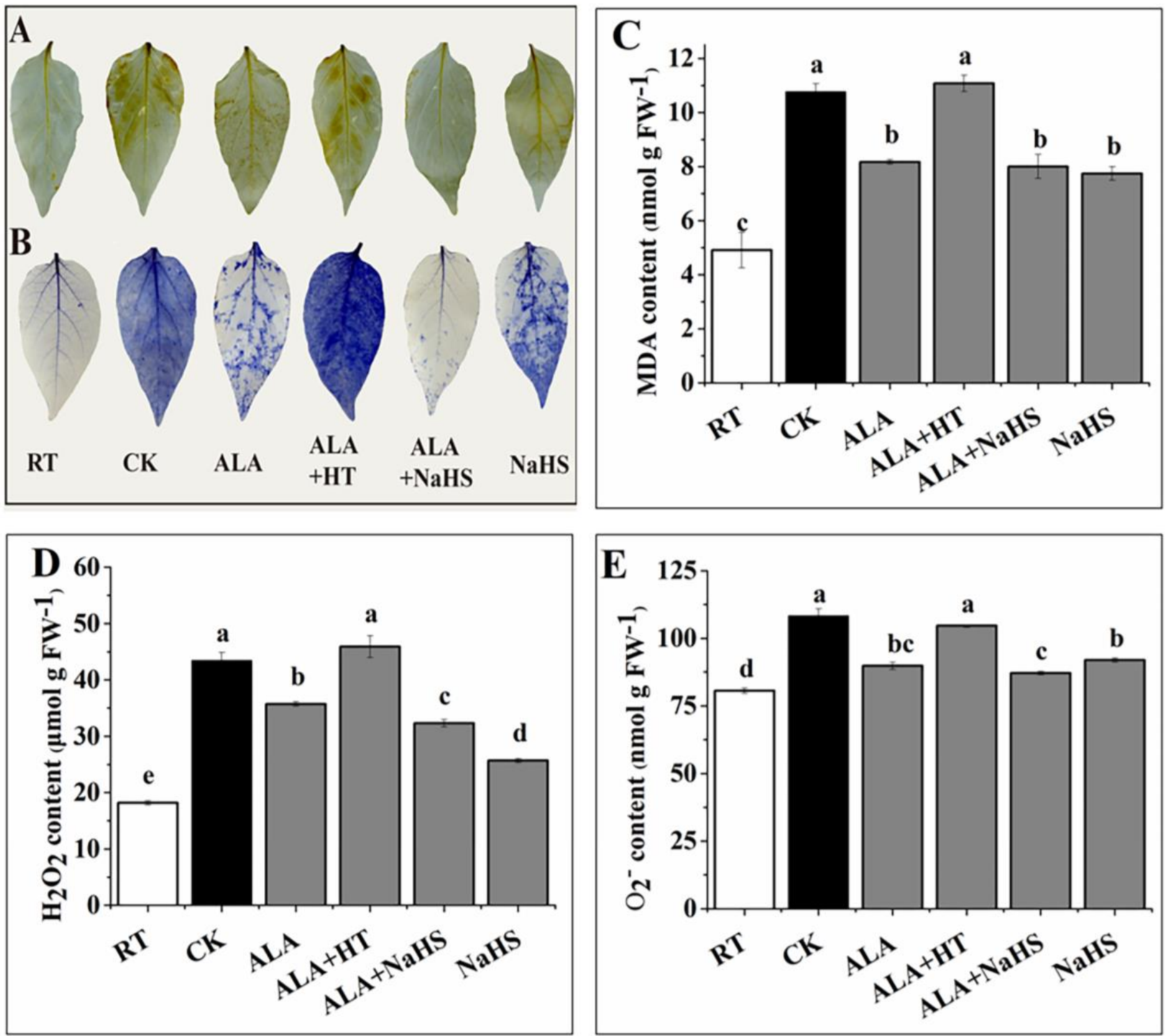

Figure 2. Effects of ALA and/or $\mathrm{H}_{2} \mathrm{~S}$ on DAB staining (A), NBT staining (B), the contents of MDA (C), $\mathrm{H}_{2} \mathrm{O}_{2}(\mathbf{D})$, and $\mathrm{O}_{2}{ }^{\bullet-}$ (E) under chilling stress for $24 \mathrm{~h}$. The error bars are the standard errors for three independent tests. Different letters show significant differences $(p<0.05)$ based on Duncan's test.

\subsection{Effects of $A L A$ and/or $\mathrm{H}_{2} \mathrm{~S}$ on the Contents of AsA and DHA under Chilling Stress}

As shown in Figure 5, chilling stress markedly reduced the content of AsA and increased the content of DHA (Figure 5A,B). Compared to CK, the ALA, NaHS, ALA + NaHS, and ALA + HT treatments increased the content of AsA by $17.9 \%, 20.3 \%, 24.4 \%$, and $5.6 \%$, respectively (Figure 5A). Meanwhile, compared to CK, the ALA, NaHS, and ALA + NaHS treatments decreased the content of DHA by $33.7 \%, 34.8 \%$, and $44.7 \%$, respectively (Figure $5 \mathrm{~B}$ ), and the AsA/DHA ratio increased by $77.4 \%, 84.3 \%$, and $124.4 \%$, respectively (Figure 5C). No significant differences in DHA content and AsA/DHA ratio were found between the ALA + HT and CK groups (Figure $5 B, C$ ). 


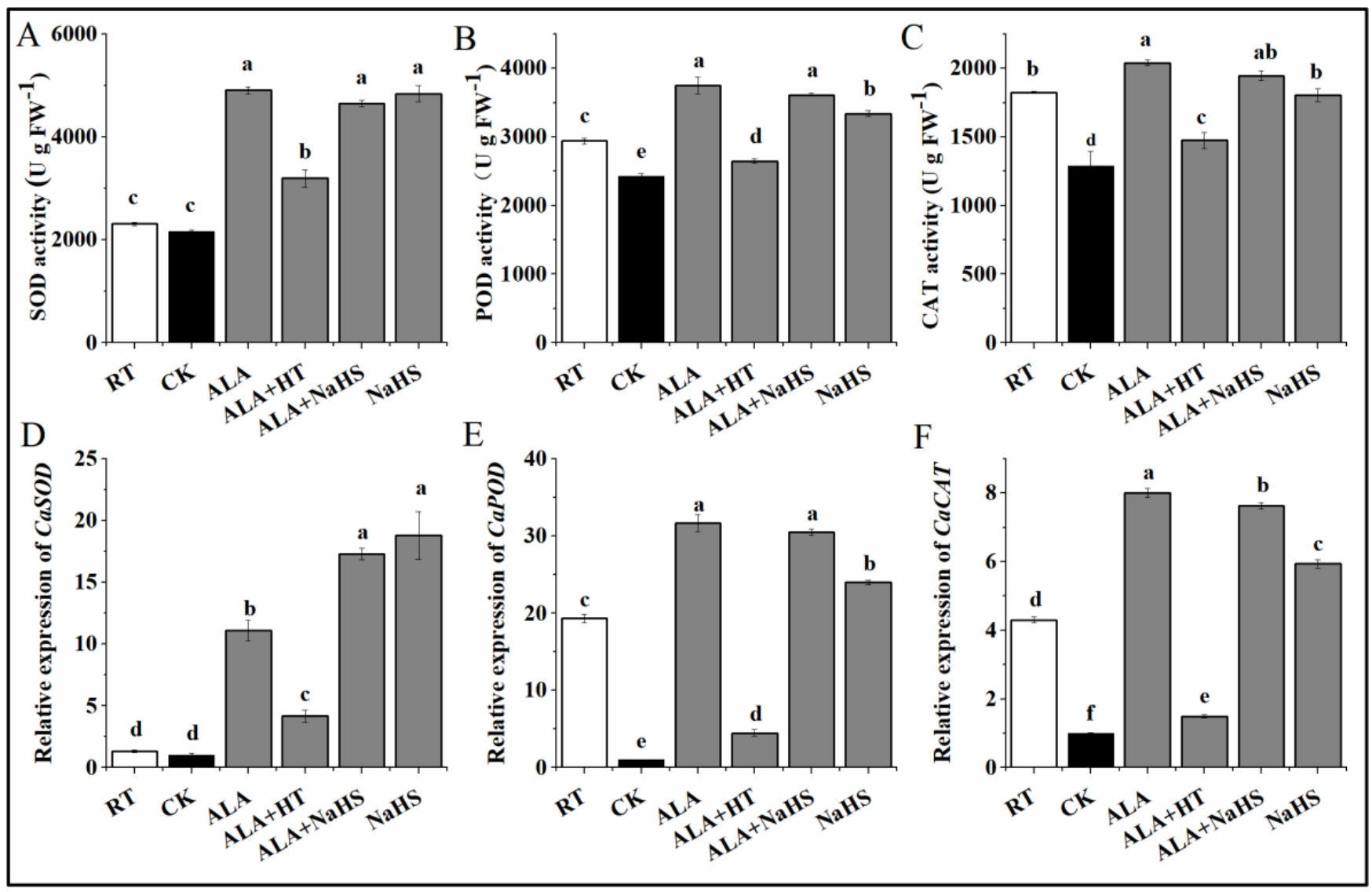

Figure 3. Effects of ALA and/or $\mathrm{H}_{2} \mathrm{~S}$ on $\mathrm{SOD}(\mathbf{A})$, POD (B), and CAT (C) activities and the relative expressions of CaSOD (D), CaPOD (E), and CaCAT (F) under chilling stress for $24 \mathrm{~h}$. The error bars are the standard errors for three independent tests. Different letters show significant differences $(p<0.05)$ based on Duncan's test.

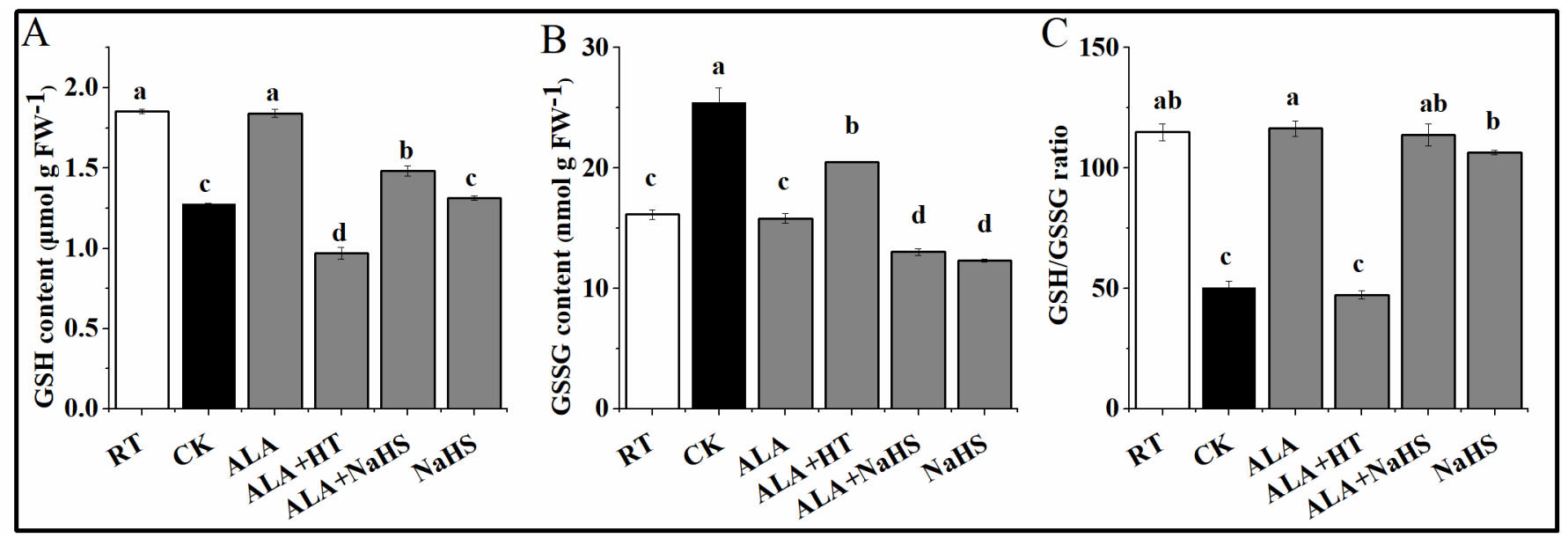

Figure 4. Effects of ALA and/or $\mathrm{H}_{2} \mathrm{~S}$ on the contents of GSH (A), GSSG (B), and GSH/GSSH ratio (C) under chilling stress for $24 \mathrm{~h}$. The error bars are the standard errors for three independent tests. Different letters show significant differences $(p<0.05)$ based on Duncan's test. 


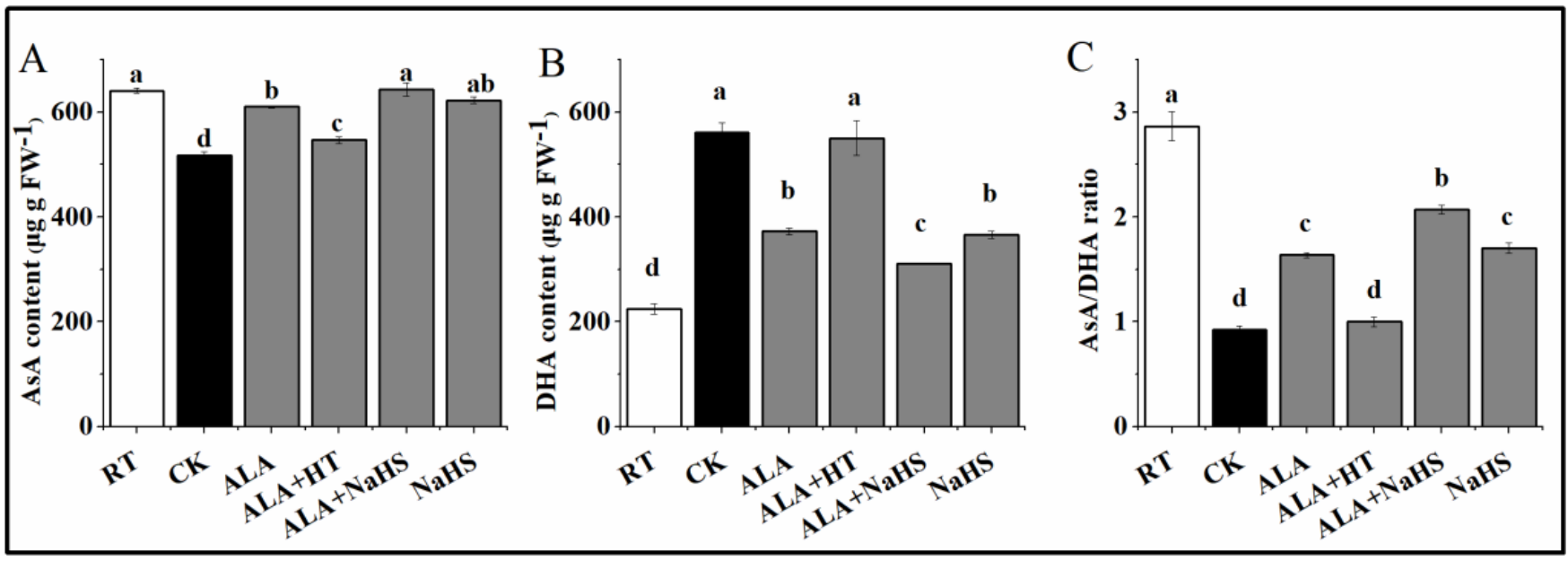

Figure 5. Effects of ALA and/or $\mathrm{H}_{2} \mathrm{~S}$ on the contents of AsA (A), DHA (B), and AsA/DHA ratio (C) under chilling stress for $24 \mathrm{~h}$. The error bars are the standard errors for three independent tests. Different letters show significant differences $(p<0.05)$ based on Duncan's test.

\subsection{Effects of ALA and/or $\mathrm{H}_{2} \mathrm{~S}$ on APX and GR Activity under Chilling Stress}

Figure $6 \mathrm{~A}$ shows the effects of ALA and/or $\mathrm{H}_{2} \mathrm{~S}$ on APX activity in pepper seedlings subjected to chilling stress for $24 \mathrm{~h}$. APX activity was not significantly affected by $24 \mathrm{~h}$ of chilling stress (Figure 6A). However, compared to CK, the ALA, NaHS, and ALA + NaHS treatments increased the APX activity by $55.6 \%, 71.4 \%$ and $54.5 \%$, respectively (Figure $6 \mathrm{~A}$ ). Meanwhile, the ALA, NaHS, and ALA + NaHS treatments increased the GR activity in pepper seedlings by 1.3-, 1.1-, and 1.2-fold, respectively (Figure 6B). In addition, the ALA, $\mathrm{NaHS}$, and ALA + NaHS treatments increased the relative expression of CaAPX by $98.8 \%$, $379.1 \%$, and $159.8 \%$, respectively (Figure $6 \mathrm{C}$ ), and increased the relative expression of CaGR by $41.1 \%, 76.6 \%$, and $57.1 \%$, respectively (Figure $6 \mathrm{D}$ ). No significant differences in the activities of APX and GR or in the relative expressions of CaAPX and CaGR were observed between the ALA + HT and CK groups (Figure 6A-D). These results suggest that exogenous ALA and/or $\mathrm{H}_{2} \mathrm{~S}$ enhanced the activities of APX and GR in pepper seedlings under chilling stress.

\subsection{Effects of $A L A$ and/or $\mathrm{H}_{2} \mathrm{~S}$ on DHAR and MDHAR Activity under Chilling Stress}

To further study the effects of ALA and/or $\mathrm{H}_{2} \mathrm{~S}$ on the AsA-GSH cycle, we measured the activities of DHAR and MDHAR and the transcript levels of CaDHAR and CaMDHAR. Compared to CK, the application of ALA increased the activities DHAR and MDHAR by $29.8 \%$ and $53.9 \%$, respectively, and enhanced the relative expressions of CaDHAR and CaMDHAR by $32.4 \%$ and $27.3 \%$, respectively (Figure 7A-D). Meanwhile, compared to CK, the application of NaHS increased the activities of DHAR and MDHAR by $29.4 \%$ and $53.6 \%$, respectively, and enhanced the relative expressions of $C a D H A R$ by $31.9 \%$ and $22.4 \%$, respectively (Figure 7A-C). Compared to CK, exogenous ALA + NaHS increased the activities of DHAR and MDHAR by $53.0 \%$ and $111.9 \%$, respectively, and increased the relative expressions of CaDHAR and CaMDHAR by $265.7 \%$ and $187.0 \%$, respectively (Figure 7A-D). There were no significant differences in the DHAR and MDHAR activities, or the relative expression levels of CaDHAR and CaMDHAR between the ALA + HT and CK groups (Figure 7A-D). These results suggest that ALA and $\mathrm{H}_{2} \mathrm{~S}$ enhanced the relative expressions of $\mathrm{CaAPX}, \mathrm{CaGR}, \mathrm{CaDHAR}$, and CaMDHAR in pepper seedlings under chilling stress, with the combination of ALA and NaHS having the most significant effect. 


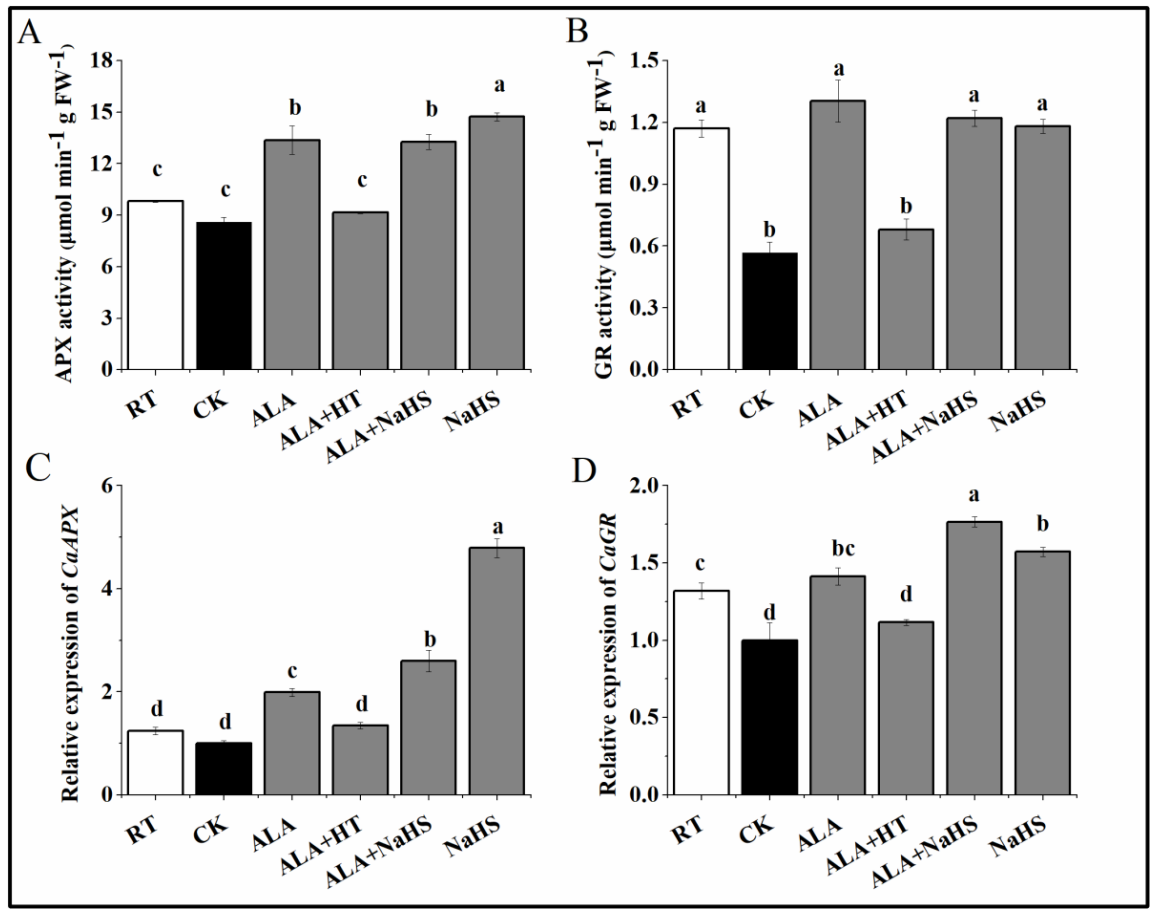

Figure 6. Effects of ALA and/or $\mathrm{H}_{2} \mathrm{~S}$ on the activities of APX (A) and GR (B) and the relative expressions of $C a A P X(\mathbf{C})$ and $C a G R(D)$ under chilling stress for $24 \mathrm{~h}$. The error bars are the standard errors for three independent tests. Different letters show significant differences $(p<0.05)$ based on Duncan's test.

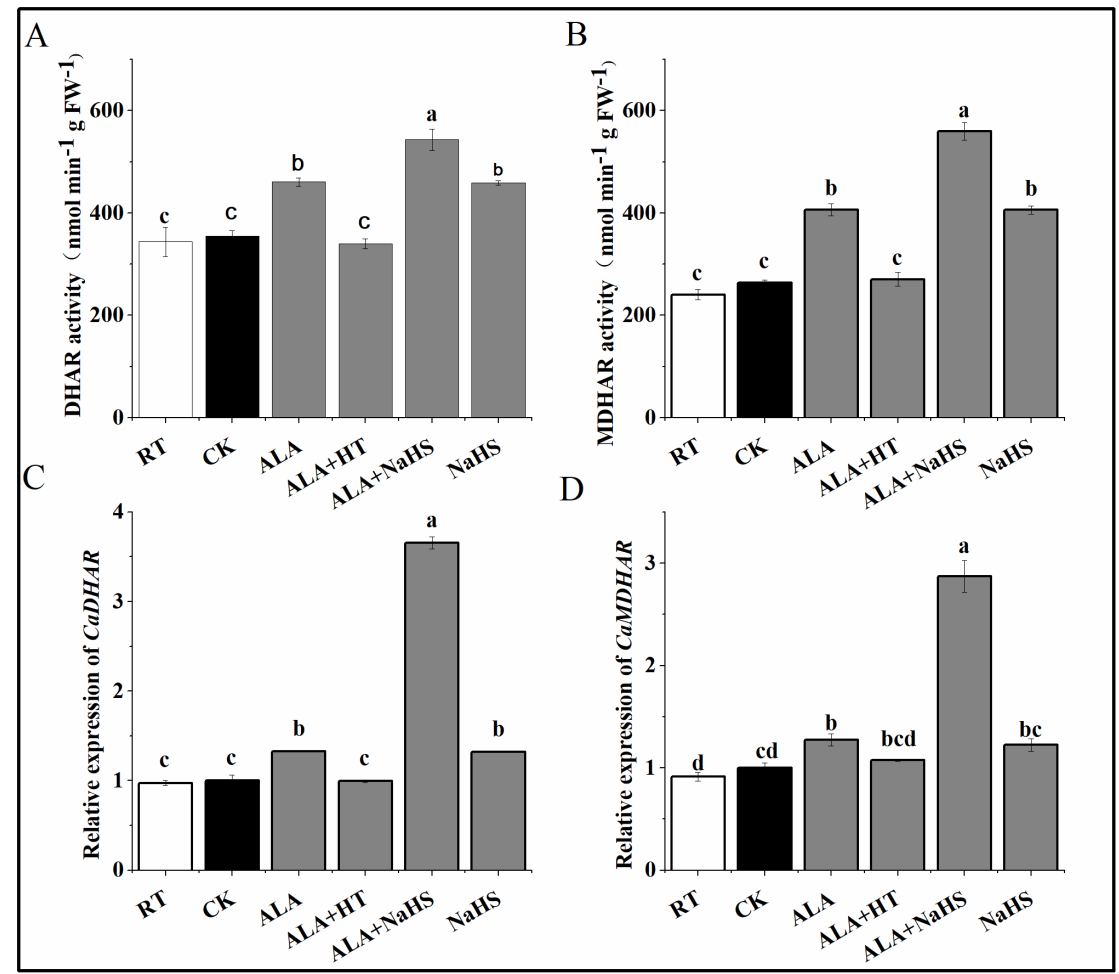

Figure 7. Effects of ALA and/or $\mathrm{H}_{2} \mathrm{~S}$ on the activities of DHAR (A) and MDHAR (B) and the relative expressions of CaDHAR (C) and CaMDHAR (D) under chilling stress for $24 \mathrm{~h}$. The error bars are the standard errors for three independent tests. Different letters show significant differences $(p<0.05)$ based on Duncan's test. 


\section{Discussion}

Low temperature is an important limiting factor in the production of pepper $[1,35]$. In our study, chilling stress significantly reduced the stem diameter, plant height, the number of leaves, and fresh weight of pepper seedlings. The addition of exogenous ALA significantly mediated the decreases in plant height, hypocotyl diameter, root length, plant dry weight, leaf area, and strong seedling index of cucumber and maize seedlings caused by low-temperature stress $[5,20] . \mathrm{H}_{2} \mathrm{~S}$ has also been found to increase the growth parameters and biomass of cucumber [36], and rice seedlings [37]. Similar to these findings, in this study, treatment with ALA and/or $\mathrm{H}_{2} \mathrm{~S}$ increased the stem diameter, plant height, leaves number, and fresh weight in pepper seedlings under chilling stress. In addition, the effects of the ALA and ALA + NaHS treatments were more significant than those of the NaHS treatment. However, the application of $\mathrm{HT}$ (an $\mathrm{H}_{2} \mathrm{~S}$ scavenger) significantly reduced the promotion of ALA to the growth of pepper seedlings under chilling stress, suggesting that $\mathrm{H}_{2} \mathrm{~S}$ was involved in ALA to alleviate the inhibition on the growth of pepper seedlings caused by low temperature.

The metabolic pathways in plant organelles become disordered in adverse environments, leading to the production and accumulation of ROS. The presence of excessive ROS induces oxidative stress, which results in the oxidation of cell components, affects the integrity of organelles, and impedes metabolic activity [38]. ROS play important roles in improving tolerance to abiotic stresses and maintaining normal plant growth [8]. Low temperature results in an imbalance between the light and dark reactions of protocooperation, causing the photosynthetic electron transport chain to release more superoxide $\left(\mathrm{O}_{2}{ }^{-}\right)$ via electron transfer to oxygen as a substitute electron acceptor [39]. MDA is one of the final decomposition products of membrane lipid peroxidation, and an increase in MDA content is generally considered to be indicative of membrane lipid peroxidation, which often occurs in plant tissues under abiotic stress [40,41]. In this study, cold storage increased the contents of $\mathrm{H}_{2} \mathrm{O}_{2}, \mathrm{O}_{2}{ }^{\bullet-}$, and MDA in pepper seedlings. This is consistent with the results of Tang et al. (2021), who found that serious lipid peroxidation of the cell membrane occurred under chilling stress $[1,42]$. SOD is a scavenger of $\mathrm{O}_{2}{ }^{--}$and the main enzyme producing $\mathrm{H}_{2} \mathrm{O}_{2}$. The overexpression of Mn-SOD was found to enhance the salt tolerance of Arabidopsis thaliana [43]. Moreover, exogenous SOD at chilling stress can improve the cold tolerance of plants [44]. CAT is the main scavenger of $\mathrm{H}_{2} \mathrm{O}_{2}$, and POD eliminates $\mathrm{H}_{2} \mathrm{O}_{2}$, phenols, and amines [45]. Zhao et al. (2020) reported that chilling stress increased the contents of $\mathrm{H}_{2} \mathrm{O}_{2}$ and MDA, along with the activities of SOD, POD, GR, and APX, in mung bean, while exogenous ALA enhanced the activities of antioxidant enzymes [19]. The transcript levels of SOD, APX, and MDHAR were found to decrease slightly under chilling stress in $A$. thaliana [46]. Consistent with these previous studies, our results indicate that low temperature increased the contents of $\mathrm{H}_{2} \mathrm{O}_{2}, \mathrm{O}_{2}{ }^{\bullet-}$, and MDA in pepper seedlings. However, unlike the results reported in mung beans, low temperature did not increase the activities of SOD, POD, and CAT in our study. This discrepancy may be related to the different responses of different plants to chilling stress [39]. Under chilling stress, the application of ALA was found to increase the activities of SOD and CAT in pepper, maize, and cucumber, while it decreased the content of MDA [5]. Exogenous ALA also significantly reduced the contents of MDA and $\mathrm{H}_{2} \mathrm{O}_{2}$ and enhanced the activities of SOD, POD, CAT, APX, and GR in oilseed rape under cadmium (Cd) stress [47]. $\mathrm{H}_{2} \mathrm{~S}$ inhibited oxidative damage and membrane peroxidation by activating an antioxidant enzyme system after $\mathrm{Cd}$ treatment [48]. The synergistic effect of $\mathrm{SA}$ and $\mathrm{H}_{2} \mathrm{~S}$ enhanced the antioxidant system in maize [49]. Exogenous $\mathrm{H}_{2} \mathrm{~S}$ accumulation in hawthorn fruit also enhanced the activities of L-cysteine desulfhydrase (LCD), D-cysteine desulfhydrase (DCD), SOD, CAT, and APX along with the accumulation of AsA, resulting in reduced $\mathrm{H}_{2} \mathrm{O}_{2}$ accumulation after harvest under freezing damage [50]. These studies demonstrate that $\mathrm{H}_{2} \mathrm{~S}$ can participate in antioxidant stress response through over-sulfated antioxidant enzymes [25]. In the present study, ALA and / or $\mathrm{H}_{2} \mathrm{~S}$ significantly increased the activities of SOD, POD, CAT, APX, and GR and decreased the contents of $\mathrm{H}_{2} \mathrm{O}_{2}, \mathrm{O}_{2}{ }^{\bullet-}$, and MDA in pepper seedlings 
under chilling stress. In addition, $\mathrm{H}_{2} \mathrm{~S}$ and ALA significantly enhanced the transcription levels of antioxidant enzymes.

The AsA-GSH cycle is the primary ROS scavenging system in cells [51]. GSH is a small redox-active molecule that mainly exists in two stable forms, GSH and GSSG [52]. DHA is the reversible oxidized form of AsA. As a reducing agent of DHA, GSH participates in the AsA-GSH cycle. DHA can also maintain $\alpha$-tocopherol and zeaxanthin in the reduced states and protect the proteins from denaturing via the oxidation of mercaptan groups, thereby protecting the integrity of the cell plasma membrane [53]. In normally growing plants, the GSH/GSSG ratio is high; exposure to adverse environmental conditions can alter this ratio, particularly by inducing an increase in GSSG [52]. In this study, ALA increased the content of GSH and decreased the content of GSSG in seedlings under chilling stress, causing the GSH/GSSG ratio to be similar to that under regular training. $\mathrm{H}_{2} \mathrm{~S}$ also increased the GSH/GSSG ratio by decreasing the content of GSSG. A high GSH/GSSG and/or AsA/DHA ratio may be the key to effectively ameliorating the accumulation of ROS induced by abiotic stress [27,54]. In our study, ALA and/or $\mathrm{H}_{2} \mathrm{~S}$ significantly increased the content of AsA and the AsA/DHA ratio, while they decreased the content of DHA. Treatment with ALA maintained the high AsA/DHA and GSH/GSSG ratios in Brassica napus under drought stress [55]. Similarly, $\mathrm{H}_{2} \mathrm{~S}$ was found to enhance the contents of AsA and GSH along with the enzyme activities in the AsA-GSH cycle in pea under arsenate stress [56].

APX catalyzes the reduction of $\mathrm{H}_{2} \mathrm{O}_{2}$ to $\mathrm{H}_{2} \mathrm{O}$ by using AsA as an electron donor, resulting in the formation of DHA. DHAR reduces DHA to AsA via the electrons provided by GSH. NADPH reduces GSSG to GSH under the catalysis of GR. DHA is generated from MDHA. MDHAR catalyzes the reduction of MDHA to AsA. Thus, APX, GR, DHAR, and MDHAR are the key enzymes in the AsA-GSH cycle. The overexpression of chloroplast APX in tobacco was reported to improve tolerance to chilling stress [57]. The overexpression of GR in tobacco increased the level of GSH in leaves and enhanced the resistance to oxidative stress [58]. The overexpression of DHAR increased the fresh weight, seedling length, germination rate, and chlorophyll content in tomato under salt stress [59]. Sultana et al. (2012) found that the overexpression of MDHAR in a mangrove plant conferred salt tolerance to rice [60]. In addition, the overexpression of MDHAR gene in $A$. thaliana enhanced the stress tolerance of tobacco [61]. In cucumber, the application of ALA enhanced the activities of GR, APX, DHAR, and MDHAR, and upregulated the expressions of CAT and APX genes in roots and leaves, GR in roots under salt stress [62]. $\mathrm{H}_{2} \mathrm{~S}$ is involved in antioxidant activity at multiple levels, including transcriptional and post-translational modification [25]. Exogenous ALA significantly improved the gene expressions of antioxidant enzymes in Brassica napus under Cd stress [63]. The application of ALA stimulated the expressions of SOD, CAT, GR, and DHAR genes under lead stress in Brassica juncea [64]. In the present study, ALA and/or $\mathrm{H}_{2} \mathrm{~S}$ significantly increased the activities of APX, GR, DHAR, and MDAR and enhanced the expression levels of $\mathrm{CaAPX}, \mathrm{CaGR}, \mathrm{CaDHAR}$, and CaMDHAR in pepper seedlings under chilling stress, thereby enhancing the AsA-GSH pathway.

Our research shows that both ALA and $\mathrm{H}_{2} \mathrm{~S}$ enhanced the antioxidant capacity of pepper seedlings under chilling stress to improve their cold resistance. The ALA + HT treatment had significantly negative effects on the growth of pepper seedlings and antioxidant activity compared with ALA and ALA + NaHS treatments. The application of HT increased the accumulation of ROS and the content of MDA, and decreased the ascorbate (AsA)-glutathione (GSH) cycle and the activity of antioxidant enzymes by down-regulating the gene expression of antioxidant enzymes. These findings indicated that $\mathrm{H}_{2} \mathrm{~S}$ scavenging prevented ALA from regulating the antioxidant system and cold resistance of pepper seedlings, and ALA and $\mathrm{H}_{2} \mathrm{~S}$ interact to regulate the oxidative stress response of pepper seedlings under chilling stress. 


\section{Conclusions}

The exogenous application of ALA and/or $\mathrm{H}_{2} \mathrm{~S}$ to pepper seedlings under chilling stress enhanced the antioxidant defense system. ALA and/or $\mathrm{H}_{2} \mathrm{~S}$ increased the activities of antioxidant enzymes by increasing the enzyme transcription levels. The transcription of GR, APX, DHAR, and MDHAR enhanced the AsA-GSH cycle, ultimately reducing the contents of $\mathrm{O}_{2}{ }^{\bullet-}, \mathrm{H}_{2} \mathrm{O}_{2}$, and MDA and alleviating the negative effects of low-temperature stress. Meanwhile, a combination of ALA and $\mathrm{H}_{2} \mathrm{~S}$ had better effects than treatment with ALA or $\mathrm{H}_{2} \mathrm{~S}$ alone. HT reversed the effects of ALA, indicating that the antioxidant effect of ALA requires the participation of $\mathrm{H}_{2} \mathrm{~S}$.

Author Contributions: H.W. and J.X. designed the research. H.W. and Z.L. performed the data analysis. H.W. wrote the manuscript. J.L., J.Z., S.L. and J.X. revised the manuscript. All authors have read and agreed to the published version of the manuscript.

Funding: This work was supported by the Special Fund Project of Leading Science and Technology Innovation Development of Gansu Province, China (2018ZX02), the Special Fund for Technical System of Melon and Vegetable Industry of Gansu Province, China (GARS-GC-1), and the National Key Research and Development Program of China (2016YFD0201005).

Institutional Review Board Statement: Not applicable.

Informed Consent Statement: Not applicable.

Data Availability Statement: Not applicable.

Conflicts of Interest: The authors declare no conflict of interest.

\section{References}

1. Tang, C.; Xie, J.; Lv, J.; Li, J.; Zhang, J.; Wang, C.; Liang, G. Alleviating damage of photosystem and oxidative stress from chilling stress with exogenous zeaxanthin in pepper (Capsicum annuum L.) seedlings. Plant Physiol. Biochem. 2021, 162, 395-409. [CrossRef] [PubMed]

2. Guo, W.L.; Chen, R.G.; Gong, Z.H.; Yin, Y.X.; Li, D.W.; Pandey, G.K. Suppression Subtractive Hybridization Analysis of Genes Regulated by Application of Exogenous Abscisic Acid in Pepper Plant (Capsicum annuum L.) Leaves under Chilling Stress. PLoS ONE 2013, 8, e66667. [CrossRef] [PubMed]

3. Yadav, S.K. Cold stress tolerance mechanisms in plants. A review. Agron. Sustain. Dev. 2010, 30, 515-527. [CrossRef]

4. Lu, Y.; Hu, Y.; Snyder, R.L.; Kent, E.R. Tea leaf's microstructure and ultrastructure response to low temperature in indicating critical damage temperature. Inf. Processing Agric. 2019, 6, 247-254. [CrossRef]

5. Anwar, A.; Yan, Y.; Liu, Y.; Li, Y.; Yu, X. 5-Aminolevulinic Acid Improves Nutrient Uptake and Endogenous Hormone Accumulation, Enhancing Low-Temperature Stress Tolerance in Cucumbers. Int. J. Mol. Sci. 2018, 19, 3379. [CrossRef]

6. Ma, X.; Chen, C.; Yang, M.; Dong, X.; Lv, W.; Meng, Q. Cold-regulated protein (SICOR413IM1) confers chilling stress tolerance in tomato plants. Plant Physiol. Biochem. 2018, 124, 29-39. [CrossRef]

7. Singh, S.; Kumar, V.; Kapoor, D.; Kumar, S.; Singh, S.; Dhanjal, D.S.; Datta, S.; Samuel, J.; Dey, P.; Wang, S.; et al. Revealing on hydrogen sulfide and nitric oxide signals co-ordination for plant growth under stress conditions. Physiol. Plant. 2020, 168, 301-317. [CrossRef]

8. Huang, H.; Ullah, F.; Zhou, D.X.; Yi, M.; Zhao, Y. Mechanisms of ROS Regulation of Plant Development and Stress Responses. Front. Plant Sci. 2019, 10, 800. [CrossRef]

9. Miller, G.; Suzuki, N.; Ciftci-Yilmaz, S.; Mittler, R. Reactive oxygen species homeostasis and signalling during drought and salinity stresses. Plant Cell Environ. 2010, 33, 453-467. [CrossRef]

10. Gill, S.S.; Tuteja, N. Reactive oxygen species and antioxidant machinery in abiotic stress tolerance in crop plants. Plant Physiol. Biochem. 2010, 48, 909-930. [CrossRef]

11. Schippers, J.; Nguyen, H.M.; Lu, D.; Schmidt, R.; Mueller-Roeber, B. ROS homeostasis during development: An evolutionary conserved strategy. Cell. Mol. Life Sci. 2012, 69, 3245. [CrossRef] [PubMed]

12. Seth, C.S.; Remans, T.; Keunen, E.; Jozefczak, M.; Gielen, H.; Opdenakker, K.; Weyens, N.; Vangronsveld, J.; Cuypers, A. Phytoextraction of toxic metals: A central role for glutathione. Plant Cell Environ. 2012, 35, 334-346. [CrossRef] [PubMed]

13. Kaya, C.; Ashraf, M.; Akram, N.A. Hydrogen sulfide regulates the levels of key metabolites and antioxidant defense system to counteract oxidative stress in pepper ( Capsicum annuum L.) plants exposed to high zinc regime. Environ. Sci. Pollut. Res. 2018, 25, 12612-12618. [CrossRef] [PubMed]

14. Zulfiqar, F.; Hancock, J.T. Hydrogen sulfide in horticulture: Emerging roles in the era of climate change. Plant Physiol. Biochem. 2020, 155, 667-675. [CrossRef] [PubMed] 
15. Liu, T.; Hu, X.; Zhang, J.; Zhang, J.; Du, Q.; Li, J. $\mathrm{H}_{2} \mathrm{O}_{2}$ mediates ALA-induced glutathione and ascorbate accumulation in the perception and resistance to oxidative stress in Solanum lycopersicum at low temperatures. BMC Plant Biol. 2018, 18, 34 . [CrossRef]

16. Wu, Y.; Liao, W.; Dawuda, M.M.; Hu, L.; Yu, J. 5-Aminolevulinic acid (ALA) biosynthetic and metabolic pathways and its role in higher plants: A review. Plant Growth Regul. 2018, 87, 357-374. [CrossRef]

17. Balestrasse, K.B.; Tomaro, M.L.; Batlle, A.; Noriega, G.O. The role of 5-aminolevulinic acid in the response to cold stress in soybean plants. Phytochemistry 2010, 71, 2038-2045. [CrossRef]

18. Akram, N.A.; Ashraf, M. Regulation in Plant Stress Tolerance by a Potential Plant Growth Regulator, 5-Aminolevulinic Acid. J. Plant Growth Regul. 2013, 32, 663-679. [CrossRef]

19. Rhaman, M.S.; Imran, S.; Karim, M.M.; Chakrobortty, J.; Mahamud, M.A.; Sarker, P.; Tahjib-Ul-Arif, M.; Robin, A.H.K.; Ye, W.; Murata, Y.; et al. 5-aminolevulinic acid-mediated plant adaptive responses to abiotic stress. Plant Cell Rep. 2021, 40, 1451-1469. [CrossRef]

20. Liu, T.; Xu, J.; Zhang, J.; Li, J.; Hu, X. Exogenous 5-aminolevulinic acid pretreatment ameliorates oxidative stress triggered by low-temperature stress of Solanum lycopersicum. Acta Physiol. Plant. 2018, 40, 1-11. [CrossRef]

21. Zhao, J.J.; Zhou, N.; Feng, N.J.; Zheng, D.F. Effects of 5-aminolevulinic acid on osmotic adjustment and antioxidant system in mung bean under chilling stress. Biol. Plant. 2020, 64, 736-743. [CrossRef]

22. Wang, Y.; Li, J.; Gu, W.; Qian, Z.; Tian, L.; Guo, S.; Wei, S. Exogenous application of 5-aminolevulinic acid improves lowtemperature stress tolerance of maize seedlings. Crop Pasture Sci. 2018, 69, 587-593. [CrossRef]

23. Sheteiwy, M.; Shen, H.; Xu, J.; Guan, Y.; Song, W.; Hu, J. Seed polyamines metabolism induced by seed priming with spermidine and 5-aminolevulinic acid for chilling tolerance improvement in rice (Oryza sativa L.) seedlings. Environ. Exp. Bot. 2017, 137, 58-72. [CrossRef]

24. Wang, R. Gasotransmitters: Growing pains and joys. Trends Biochem. Sci. 2014, 39, 227-232. [CrossRef] [PubMed]

25. Gotor, C.; García, I.; Aroca, N.; Laureano-Marín, A.; Romero, L.C. Signaling by hydrogen sulfide and cyanide through posttranslational modification. J. Exp. Bot. 2019, 70, 4251-4265. [CrossRef]

26. Du, X.; Jin, Z.; Liu, D.; Yang, G.; Pei, Y. Hydrogen sulfide alleviates the cold stress through MPK4 in Arabidopsis thaliana. Plant Physiol. Biochem. 2017, 120, 112-119. [CrossRef]

27. Chen, T.; Tian, M.; Han, Y. Hydrogen sulfide: A multi-tasking signal molecule in the regulation of oxidative stress responses. $J$. Exp. Bot. 2020, 71, 2862-2869. [CrossRef]

28. Li, Z.; Zhu, Y.; He, X.; Yong, B.; Peng, Y.; Zhang, X.; Xiao, M.; Yan, Y.; Huang, L.; Nie, G. The hydrogen sulfide, a downstream signaling molecule of hydrogen peroxide and nitric oxide, involves spermidine-regulated transcription factors and antioxidant defense in white clover in response to dehydration. Environ. Exp. Bot. 2018, 161, 255-264. [CrossRef]

29. Fu, P.; Wang, W.; Hou, L.; Liu, X. Hydrogen sulfide is involved in the chilling stress response in Vitis vinifera L. Acta Soc. Bot. Pol. 2013, 82, 295-302. [CrossRef]

30. Zhang, X.W.; Liu, F.J.; Zhai, J.; Li, F.D.; Bi, H.G.; Ai, X.Z. Auxin acts as a downstream signaling molecule involved in hydrogen sulfide-induced chilling tolerance in cucumber. Planta 2020, 251, 69. [CrossRef]

31. Fu, J.J.; $\mathrm{Chu}$, X.T.; Sun, Y.F.; Xu, Y.F.; Hu, T.M. Involvement of nitric oxide in 5-aminolevulinic acid-induced antioxidant defense in roots of Elymus nutans exposed to cold stress. Biol. Plant. 2016, 60, 1-10. [CrossRef]

32. Liu, T.; Xu, J.; Li, J.; Hu, X. NO is involved in JA- and $\mathrm{H}_{2} \mathrm{O}_{2}$-mediated ALA-induced oxidative stress tolerance at low temperatures in tomato. Environ. Exp. Bot. 2019, 161, 334-343. [CrossRef]

33. Pan, D.Y.; Fu, X.; Zhang, X.W.; Liu, F.J.; Bi, H.G.; Ai, X.Z. Hydrogen sulfide is required for salicylic acid-induced chilling tolerance of cucumber seedlings. Protoplasma 2020, 257, 1543-1557. [CrossRef] [PubMed]

34. Wang, Y.; Li, L.; Cui, W.; Xu, S.; Shen, W.; Wang, R. Hydrogen sulfide enhances alfalfa (Medicago sativa) tolerance against salinity during seed germination by nitric oxide pathway. Plant Soil 2012, 351, 107-119. [CrossRef]

35. Li, Z.G.; Yang, S.Z.; Long, W.B.; Yang, G.X.; Shen, Z.Z. Hydrogen sulfide may be a novel downstream signal molecule in nitric oxide-induced heat tolerance of maize (Zea mays L.) seedlings. Plant Cell Environ. Plant Cell Environ. 2013, 36, 1564-1572. [CrossRef]

36. Fang, H.; Jing, T.; Liu, Z.; Zhang, L.; Jin, Z.; Pei, Y. Hydrogen sulfide interacts with calcium signaling to enhance the chromium tolerance in Setaria italica. Cell Calcium Int. Interdiscip. Forum Res. Calcium 2014, 56, 472-481. [CrossRef]

37. Wang, H.; Liu, Z.; Luo, S.; Li, J.; Zhang, J.; Li, L.; Xie, J. 5-Aminolevulinic acid and hydrogen sulphide alleviate chilling stress in pepper (Capsicum annuum L.) seedlings by enhancing chlorophyll synthesis pathway. Plant Physiol. Biochem. 2021, 167, 567-576. [CrossRef]

38. Korkmaz, A.; Korkmaz, Y.; Demirkıran, A.R. Enhancing chilling stress tolerance of pepper seedlings by exogenous application of 5-aminolevulinic acid. Environ. Exp. Bot. 2010, 67, 495-501. [CrossRef]

39. Wu, G.X.; Cai, B.B.; Zhou, C.F.; Li, D.D.; Bi, H.G.; Ai, X.Z. Hydrogen sulfide-induced chilling tolerance of cucumber and involvement of nitric oxide. J. Plant Biol. Res. 2016, 5, 58-69.

40. Duan, B.; Ma, Y.; Jiang, M.; Yang, F.; Ni, L.; Lu, W. Improvement of photosynthesis in rice (Oryza sativa L.) as a result of an increase in stomatal aperture and density by exogenous hydrogen sulfide treatment. Plant Growth Regul. 2014, 75, 33-44. [CrossRef]

41. Suzuki, N.; Koussevitzky, S.; Mittler, R.; Miller, G. ROS and redox signalling in the response of plants to abiotic stress. Plant Cell Environ. 2012, 35, 259-270. [CrossRef] [PubMed] 
42. Dreyer, A.; Dietz, K.-J. Reactive Oxygen Species and the Redox-Regulatory Network in Cold Stress Acclimation. Antioxidants 2018, 7, 169. [CrossRef] [PubMed]

43. Qiu, Z.B.; Li, J.T.; Zhang, M.M.; Bi, Z.Z.; Li, Z.L. He-Ne laser pretreatment protects wheat seedlings against cadmium-induced oxidative stress. Ecotoxicol. Environ. Saf. 2013, 88, 135-141. [CrossRef] [PubMed]

44. Chen, Q.; Zhang, M.; Shen, S. Effect of salt on malondialdehyde and antioxidant enzymes in seedling roots of Jerusalem artichoke (Helianthus tuberosus L.). Acta Physiol. Plant. 2010, 33, 273-278. [CrossRef]

45. Wu, Y.; Hu, L.; Liao, W.; Mujitaba Dawuda, M.; Lyu, J.; Xie, J.; Feng, Z.; Calderón-Urrea, A.; Yu, J. Foliar application of 5-aminolevulinic acid (ALA) alleviates $\mathrm{NaCl}$ stress in cucumber (Cucumis sativus L.) seedlings through the enhancement of ascorbate-glutathione cycle. Sci. Hortic. 2019, 257, 108761. [CrossRef]

46. Wang, Y.; Yin, Y.; Jia, C.; Wang, X. TransgenicArabidopsis overexpressing Mn-SOD enhanced salt-tolerance. Plant Sci. 2004, 167, 671-677. [CrossRef]

47. Wang, X. Effects of exogenous SOD on physiological characteristics of Petunia hybrida uder low temperature stress. Seed 2021, $40,108-112$

48. Juszczak, I.; Cvetkovic, J.; Zuther, E.; Hincha, D.K.; Baier, M. Natural Variation of Cold Deacclimation Correlates with Variation of Cold-Acclimation of the Plastid Antioxidant System in Arabidopsis thaliana Accessions. Front. Plant Sci. 2016, 7, 305. [CrossRef]

49. Ali, B.; Huang, C.R.; Qi, Z.Y.; Ali, S.; Daud, M.K.; Geng, X.X.; Liu, H.B.; Zhou, W.J. 5-Aminolevulinic acid ameliorates cadmiuminduced morphological, biochemical, and ultrastructural changes in seedlings of oilseed rape. Environ. Sci. Pollut. Res. 2013, 20, 7256-7267. [CrossRef]

50. Luo, S.; Tang, Z.; Yu, J.; Liao, W.; Xie, J.; Lv, J.; Feng, Z.; Dawuda, M.M. Hydrogen sulfide negatively regulates cd-induced cell death in cucumber (Cucumis sativus L) root tip cells. BMC Plant Biol. 2020, 20, 480. [CrossRef]

51. Li, Z.G. Synergistic effect of antioxidant system and osmolyte in hydrogen sulfide and salicylic acid crosstalk-induced heat tolerance in maize (Zea mays L.) seedlings. Plant Signal. Behav. 2015, 10, e1051278. [CrossRef] [PubMed]

52. Aghdam, M.S.; Mahmoudi, R.; Razavi, F.; Rabiei, V.; Soleimani, A. Hydrogen sulfide treatment confers chilling tolerance in hawthorn fruit during cold storage by triggering endogenous $\mathrm{H} 2 \mathrm{~S}$ accumulation, enhancing antioxidant enzymes activity and promoting phenols accumulation. Sci. Hortic. 2018, 238, 264-271. [CrossRef]

53. Avashthi, H.; Pathak, R.K.; Pandey, N.; Arora, S.; Mishra, A.K.; Gupta, V.K.; Ramteke, P.W.; Kumar, A. Transcriptome-wide identification of genes involved in Ascorbate-Glutathione cycle (Halliwell-Asada pathway) and related pathway for elucidating its role in antioxidative potential in finger millet (Eleusine coracana (L.)). 3 Biotech 2018, 8, 499. [CrossRef]

54. Rahantaniaina, M.S.; Tuzet, A.; Mhamdi, A.; Noctor, G. Missing links in understanding redox signaling via thiol/disulfide modulation: How is glutathione oxidized in plants? Front. Plant Sci. 2013, 4, 477. [CrossRef] [PubMed]

55. Fotopoulos, V.; Ziogas, V.; Tanou, G.; Molassiotis, A. Involvement of AsA/DHA and GSH/GSSG Ratios in Gene and Protein Expression and in the Activation of Defence Mechanisms Under Abiotic Stress Conditions. In Ascorbate-Glutathione Pathway and Stress Tolerance in Plants; Springer: Dordrecht, The Netherlands, 2010; pp. 265-302.

56. Szalai, G.; Kells, T.; Galiba, G.; Kocsy, G. Glutathione as an Antioxidant and Regulatory Molecule in Plants under Abiotic Stress Conditions. J. Plant Growth Regul. 2009, 28, 66-80. [CrossRef]

57. Liu, D.; Pei, Z.F.; Naeem, M.S.; Ming, D.F.; Liu, H.B.; Khan, F.; Zhou, W.J. 5-Aminolevulinic Acid Activates Antioxidative Defence System and Seedling Growth in Brassica napus L. under Water Deficit Stress. J. Agron. Crop Sci. 2011, 197, 284-295. [CrossRef]

58. Singh, V.P.; Singh, S.; Kumar, J.; Prasad, S.M. Hydrogen sulfide alleviates toxic effects of arsenate in pea seedlings through up-regulation of the ascorbate-glutathione cycle: Possible involvement of nitric oxide. J. Plant Physiol. 2015, 181, 20-29. [CrossRef]

59. Yabuta, Y.; Motoki, T.; Yoshimura, K.; Takeda, T.; Ishikawa, T.; Shigeoka, S. Thylakoid membrane-bound ascorbate peroxidase is a limiting factor of antioxidative systems under photo-oxidative stress. Plant J. 2002, 32, 915-925. [CrossRef]

60. Broadbent, P.; Creissen, G.P.; Kular, B.; Wellburn, A.R.; Mullineaux, P.M. Oxidative stress responses in transgenic tobacco containing altered levels of glutathione reductase activity. Plant J. 1995, 8, 247-255. [CrossRef]

61. Li, Q.; Li, Y.; Li, C.; Yu, X. Enhanced Ascorbic Acid Accumulation through Overexpression of Dehydroascorbate Reductase Confers Tolerance to Methyl Viologen and Salt Stresses in Tomato. Czech J. Genet. Plant Breed. 2012, 48, 74-86. [CrossRef]

62. Sultana, S.; Khew, C.Y.; Morshed, M.M.; Namasivayam, P.; Napis, S.; Ho, C.L. Overexpression of monodehydroascorbate reductase from a mangrove plant (AeMDHAR) confers salt tolerance on rice. J. Plant Physiol. 2012, 169, 311-318. [CrossRef] [PubMed]

63. Eltayeb, A.E.; Kawano, N.; Badawi, G.H.; Kaminaka, H.; Sanekata, T.; Shibahara, T.; Inanaga, S.; Tanaka, K. Overexpression of monodehydroascorbate reductase in transgenic tobacco confers enhanced tolerance to ozone, salt and polyethylene glycol stresses. Planta 2007, 225, 1255-1264. [CrossRef] [PubMed]

64. Zhen, A.; Bie, Z.L.; Huang, Y.; Liu, Z.X.; Fan, M.L. Effects of 5-aminolevulinic acid on the H2O2-content and antioxidative enzyme gene expression in NaCl-treated cucumber seedlings. Biol. Plant. 2012, 56, 566-570. [CrossRef] 